\title{
IRF9 wt Allele
}

National Cancer Institute

\section{Source}

National Cancer Institute. IRF9 wt Allele. NCI Thesaurus. Code C104655.

Human IRF9 wild-type allele is located in the vicinity of $14 q 11.2$ and is approximately $6 \mathrm{~kb}$ in length. This allele, which encodes interferon regulatory factor 9 protein, is involved in both transcription regulation and signaling by type I interferons. 